\title{
A Systematic Literature Review of Brand Commitment: Definitions, Perspectives and Dimensions
}

\author{
By Sergio Andrés Osuna Ramírez \\ Cleopatra Veloutsou ${ }^{\dagger}$ \\ Anna Morgan-Thomas
}

\begin{abstract}
Although the relevance of consumer brand commitment is well recognized in the marketing literature, the multiple definitions, dimensions and conceptual approaches to the construct make it ambiguous and difficult to understand. Brand commitment often gets confused with other constructs such as brand loyalty, which further hampers its comprehension. The purpose of this paper is to enhance the theoretical foundations of the brand commitment construct by elaborating on its definition, the importance of its implications, and differentiating it from other concepts. To do so, a systematic review of the brand commitment literature is conducted. Following previously established inclusion and exclusion criteria for selection a total of 98 journal articles publish in the period 1998 to 2015 are analysed. Nine definitions of brand commitment are found in the literature, and a unified definition of the construct is advanced. The dimensions of brand commitment are analysed, and the main differences of the construct with other concepts are also clarified.
\end{abstract}

Keywords: brand commitment, brand loyalty, systematic literature review.

\section{Introduction}

Brand commitment is an important concept that marketing academics have researched for some time, but the way it is approached has changed through the years. Early work on brand commitment focused on how the construct helps to explain the relationship between behaviour and attitude (Kiesler, 1971) and emphasised how commitment simplifies consumer's decision-making process (Cohen and Houston, 1972). Later research explored the relationship between the level of consumer commitment and brand selection, considering its implications for market segmentation and advertising strategy (Grossbart et al., 1987; Lastovicka and Gardner, 1979; Robertson, 1976; Traylor, 1981). These works considered brand commitment to be an attitudinal construct. In the early nineties, Martin and Goodell (1991) examined the variation of consumers' perspectives of products according to their level of commitment, conceptualising commitment as a stronger construct that simply repeat

\footnotetext{
* Professor, Universidad EIA, Colombia.

${ }^{\dagger}$ Head, Marketing Research Unit, ATINER \& Senior Lecturer, Department of Business and Management, University of Glasgow, Scotland, UK.

* Senior Lecturer of Management, University of Glasgow, Scotland, UK.
} 
purchase behaviour, due to its attitudinal and behavioural dimensions. More recently, brand commitment is considered as key to the creation and preservation of consumer brand relationships (Fournier 1998; Fullerton, 2003).

An unfiltered search of the academic publications on brand commitment in the EBSCO database from 1960 to 2015 shows that $84 \%$ of the articles were published in the 2006-2015 time period, and 53\% in the 2011-2015 time period. The recent growth in interest brand commitment is not surprising, given the importance of the positive outcomes of the construct for managers and practitioners. One important positive outcome is purchase/repurchase intentions (Fullerton, 2005; Hur et al., 2011; Kim et al., 2008; Lacey, 2007; Shuv-Ami, 2012; Wang, 2002), defined as repeat patronage (Lacey, 2007). Another notorious positive outcome of brand commitment is recommendation/ positive word-of-mouth (Albert and Merunka, 2013; Hur et al., 2011; Kim et al., 2008; Shuv-Ami, 2012;), conceptualised as "the degree to which the consumer praises the brand to others" (Carroll and Ahuvia, 2006: page 82). Also, willingness to pay a price premium, viewed as repeat patronage even after a price increase, is considered to be a relevant outcome of brand commitment (Albert and Merunka, 2013). Furthermore, self-brand connection, or the use of the brand for the creation and representation of a desired selfimage, is also considered a significant outcome of brand commitment (Kemp and Bui, 2011). Due to the positive outcomes of the construct, a solid base of committed consumers can drive the organization to increased business and growth (Kemp et al., 2014).

Given the development of the concept of brand commitment over time, it is not surprising that several definitions of the concept can be found in the marketing literature, as well as different dimensions that explain the nature of the construct. The recent proliferation of articles on brand commitment, without the clarity of its true nature, raises concerns about its theoretical consolidation. Explaining brand commitment with its dimensions -affective, calculative and normative- is a recent practice. Affective commitment is present in all the papers that emphasise on the dimensions of the construct, followed in frequency of appearance by calculative commitment. Normative commitment, on the other hand, is rarely found in the literature that explains the construct with its dimensions. The use of different -and sometimes overlapping-definitions and theoretical models that use diverse dimensions to explain the construct has made difficult to reach an agreement among researchers, probably hindering progress in understanding. This brings the risk of duplicating empirical research and leaving relevant knowledge gaps. Another problem is related to the lack of a clear differentiation of brand commitment with other constructs like brand involvement (Wolny and Mueller, 2013), brand love (Papista and Dimitriadis, 2012), and brand passion (Albert et al., 2013). However, from the marketing literature, brand loyalty is the construct that seems to have the closest relationship with brand commitment (Fullerton, 2005; Heere and Dickson, 2008; Lariviere et al., 2014; Phau and Cheong, 2009). As a matter of fact, some authors consider brand commitment as the key element that separates spurious loyalty from genuine or true brand 
loyalty (Kim et al., 2008; Lacey, 2007). Nevertheless, there is confusion regarding the differences between these two constructs. Furthermore, brand commitment and brand loyalty are used interchangeable by several authors (Carroll and Ahuvia, 2006; Fournier, 1998; Matthews et al., 2014; Morgan and Hunt, 1994; Thomson et al., 2005). The differentiation of the constructs, recognising how they are interconnected, is key priority for researchers, as each concept is provided with a clear discriminant validity, as well as for practitioners, as they are able to focus their attention more efficiently to obtain better results.

To address these problems, and given the relevance of brand commitment for researchers and organizations, this paper aims to enhance the theoretical conceptualisation of brand commitment by presenting a unified definition of the construct, specifying the role of its different dimensions. The paper also aims to differentiate brand commitment from other constructs, especially brand loyalty, in order to reduce the ambiguity present in the literature.

To attain the proposed aims, a systematic review of the brand commitment literature was conducted in order to map the relevant intellectual territory of the field (Tranfield et al., 2003). The search focused on recent articles on the brand commitment published in top-quality journals in the areas of marketing and branding. Ninety-eight journal articles were selected as the study sample, using a specific inclusion and exclusion criteria, in order to present, compare and contrast the different definitions, dimensions, and perspectives of brand commitment. The definition of brand loyalty is also presented, in order to make a comparison between the two constructs. A discussion on how brand commitment has evolved conceptually is provided, and conclusions and directions for future research on the topic are discussed.

\section{Systematic Review and Inclusion and Exclusion Criteria}

The study followed a systematic approach to literature search. In order to analyse the more recently published academic literature on the construct, the search protocol focused on academic publications written in English and published from 1998 to 2015. The starting point of 1998 was chosen because that year marks the publication of Fournier's (1998) article, where the importance of brand commitment in consumer-brand relationships became highlighted. Journals in the areas of marketing and branding were included in the review. A systematic review was used in order to map and assess the intellectual territory of the field, as traditional 'narrative' reviews frequently omit relevant information (Tranfield et al., 2003). The process of the review must ensure its transparency and reproducibility and should incorporate a synthesized approach to organizing the literature (Tranfield et al., 2003; Walker, 2010).

The first step of the review was the identification of the search term. In order to identify the most relevant journal articles in the field, the search involved keywords 'brand commitment' in EBSCO and Scopus databases. The 
second step was to select the most relevant journal articles for the analysis, assessing the title and the abstract of the article based on the defined inclusion and exclusion criteria (tables 1 and 2).

Table 1. Exclusion Criteria

\begin{tabular}{|c|c|c|}
\hline No. & Criteria & Reasons for exclusion \\
\hline 1 & Pre-1998 & $\begin{array}{l}\text { Consider the recent articles on the } \\
\text { topic }\end{array}$ \\
\hline 2 & Case study & Too specific and subjective \\
\hline 3 & $\begin{array}{l}\text { Organizational commitment / Employee } \\
\text { brand commitment / Community } \\
\text { commitment }\end{array}$ & $\begin{array}{l}\text { The review is concerned with } \\
\text { consumer behaviour }\end{array}$ \\
\hline
\end{tabular}

Table 2. Inclusion Criteria

\begin{tabular}{|c|c|c|}
\hline No. & Criteria & Reasons for inclusion \\
\hline 1 & Academic publication & Peer-reviewed journal articles \\
\hline 2 & Articles in English & $\begin{array}{l}\text { Most relevant journals in the area of } \\
\text { research are written in this language }\end{array}$ \\
\hline 3 & Quantitative / qualitative / conceptual & $\begin{array}{l}\text { To consider empirical evidence and } \\
\text { literature reviews }\end{array}$ \\
\hline 4 & Brand commitment & Topic under study \\
\hline 5 & Customer commitment & Closely related to brand commitment \\
\hline 6 & $\begin{array}{l}\text { Marketing Journals classified as } 2,3,4 \text {, } \\
\text { or } 4 * \text { in the ABS } 2015\end{array}$ & $\begin{array}{l}\text { Top-quality journals in the area of } \\
\text { research }\end{array}$ \\
\hline 7 & $\begin{array}{l}\text { Journals in the area of branding } \\
\text { (Journal of Brand Management and } \\
\text { Journal of Product and Brand } \\
\text { Management) }\end{array}$ & Area related to the topic under study \\
\hline
\end{tabular}

After implementing the inclusion and exclusion criteria, the final sample consisted of 98 journal articles, which are listed by journal and time period in table 3. The elimination process of the articles is shown in figure 1. 
Table 3. Study Sample by Journal and Time Period

\begin{tabular}{|c|c|c|c|c|c|c|c|}
\hline & & $1998-2003$ & & 2004-2009 & & $2010-2015$ & Total \\
\hline Journal & No & Authors & No & Authors & No & 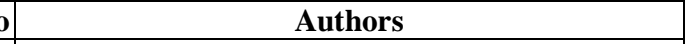 & \\
\hline Journal of Business Research & 1 & Odin et al. (2001) & 3 & $\begin{array}{l}\text { Pillai and Goldsmith (2008); Smit et al. } \\
\text { (2007); Evanschitzky et al. (2006) }\end{array}$ & 9 & $\begin{array}{l}\text { Hsiao et al. (2015); Napoli et al. (2014); Miquel- } \\
\text { Romero et al. (2014); Albert et al. (2013); Park et al. } \\
\text { (2013); Tuškej et al. (2013); Brodie et al. (2013); } \\
\text { Torres and Tribó (2011); Mollen and Wilson (2010) }\end{array}$ & 13 \\
\hline $\begin{array}{l}\text { Journal of Product and Brand } \\
\text { Management }\end{array}$ & 0 & & 1 & Horppu et al. (2008) & 6 & $\begin{array}{l}\text { Tifferet and Herstein (2012); Allaway et al. (2011); } \\
\text { Belaid and Behi (2011); Story and Hess (2010); } \\
\text { Louis and Lombart (2010); Walsh et al. (2010) }\end{array}$ & 7 \\
\hline Journal of Brand Management & 1 & Chaudhuri and Holbrook (2002) & 1 & Sung and Campbell (2009) & 4 & $\begin{array}{l}\text { Ilicic \& Webster (2014); Magnoni \& Roux, (2012); } \\
\text { Danes et al. (2012); Iglesias et al. (2011) }\end{array}$ & 6 \\
\hline Journal of Consumer Research & 2 & Coulter et al. (2003); Ahluwalia (2000) & 2 & $\begin{array}{l}\text { Raju et al. (2009); Agrawal and } \\
\text { Maheswaran (2005) }\end{array}$ & 2 & Townsend and Sood (2012); Johnson et al. (2011) & 6 \\
\hline Psychology and Marketing & 1 & Warrington and Shim (2000) & 2 & Desai and Raju (2007); Broderick (2007) & 3 & $\begin{array}{l}\text { Sung et al. (2012); Jahn et al. (2012); Sung and Choi } \\
(2010)\end{array}$ & 6 \\
\hline $\begin{array}{l}\text { Advances in Consumer } \\
\text { Research }\end{array}$ & 0 & & 4 & $\begin{array}{l}\text { Walsh et al. (2010); Raju and Unnava } \\
\text { (2006); Raju and Unnava (2005); Hansen } \\
\text { (2004) }\end{array}$ & 1 & Rajagopal and Votolato Montgomery (2012) & 5 \\
\hline $\begin{array}{l}\text { European Journal of } \\
\text { Marketing }\end{array}$ & 1 & $\begin{array}{l}\text { Delgado-Ballester and Munuera- } \\
\text { Alemán (2001) }\end{array}$ & 0 & & 4 & $\begin{array}{l}\text { Aradhita (2012); Glynn et al. (2012); Tsai (2011); } \\
\text { Svendsen et al. (2011) }\end{array}$ & 5 \\
\hline Marketing Letters & 0 & & 1 & Carroll and Ahuvia (2006) & 4 & $\begin{array}{l}\text { Germann et al. (2014); Hamilton et al. (2014); } \\
\text { Eisend and Stokburger-Sauer (2013); Swaminathan } \\
\text { et al. (2012) }\end{array}$ & 5 \\
\hline Journal of Marketing & 1 & Tax et al. (1998) & 2 & $\begin{array}{l}\text { Johnson et al. (2006); Gustafsson et al. } \\
(2005)\end{array}$ & 1 & Batra et al. (2012) & 4 \\
\hline $\begin{array}{l}\text { Journal of Marketing } \\
\text { Management }\end{array}$ & 0 & & 1 & Kim et al. (2008) & 3 & $\begin{array}{l}\text { Wolny and Mueller (2013); Michaelidou (2012); } \\
\text { Aitken and Campelo (2011); }\end{array}$ & 4 \\
\hline Journal of Services Marketing & 0 & & 0 & & 4 & $\begin{array}{l}\text { Kemp et al. (2014); Mason and Simmons (2012); } \\
\text { Magnini (2011); Jones et al. (2010) }\end{array}$ & 4 \\
\hline $\begin{array}{l}\text { International Journal of } \\
\text { Hospitality Management }\end{array}$ & 0 & & 0 & & 2 & Tanford (2013); Tanford et al. (2012) & 2 \\
\hline Journal of Advertising & 0 & & 2 & Raju et al. (2009); Kim et al. (2008) & 0 & & 2 \\
\hline \begin{tabular}{|l} 
Journal of Consumer \\
Psychology
\end{tabular} & 1 & Escalas and Bettman (2003) & 1 & Thomson et al. (2005) & 0 & & 2 \\
\hline $\begin{array}{l}\text { Journal of Marketing Theory } \\
\text { and Practice }\end{array}$ & 0 & & 1 & Lacey (2007) & 1 & Vivek et al. (2012) & 2 \\
\hline \begin{tabular}{|l} 
Journal of Retailing and \\
Consumer Services
\end{tabular} & 0 & & 1 & Sweeney and Swait (2008) & 1 & Sahagun and Vasquez-Parraga (2014) & 2 \\
\hline
\end{tabular}




\begin{tabular}{|c|c|c|c|c|c|c|c|}
\hline \multirow[b]{2}{*}{ Journal } & \multicolumn{2}{|r|}{ 1998-2003 } & \multicolumn{2}{|r|}{ 2004-2009 } & \multicolumn{2}{|r|}{ 2010-2015 } & \multirow[t]{2}{*}{ Total } \\
\hline & No & Authors & No & Authors & No & Authors & \\
\hline $\begin{array}{l}\text { Journal of Service } \\
\text { Management }\end{array}$ & 0 & & 0 & & 2 & Lariviere et al. (2014); Zhang and Bloemer (2011) & 2 \\
\hline Journal of Sport Management & 0 & & 1 & Heere and Dickson (2008) & 1 & Ferrand et al. (2010) & 2 \\
\hline $\begin{array}{l}\text { Journal of the Academy of } \\
\text { Marketing Science }\end{array}$ & 1 & Pritchard et al. (1999) & 1 & Leigh et al. (2006) & 0 & & 2 \\
\hline Business Horizons & 1 & Prince and Davies (2002) & 0 & & 0 & & 1 \\
\hline $\begin{array}{l}\text { Canadian Journal of } \\
\text { Administrative Sciences }\end{array}$ & 0 & & 1 & Fullerton (2005) & 0 & & 1 \\
\hline Decision Support Systems & 0 & & 0 & & 1 & Chang and $\mathrm{Wu}(2014)$ & 1 \\
\hline $\begin{array}{l}\text { Industrial Marketing } \\
\text { Management }\end{array}$ & 0 & & 1 & Han and Sung (2008) & 0 & & 1 \\
\hline \begin{tabular}{|l|} 
Journal of Applied Social \\
Psychology
\end{tabular} & 0 & & 0 & & 1 & Choi and Ahluwalia (2013) & 1 \\
\hline $\begin{array}{l}\text { Journal of Business \& Retail } \\
\text { Management Research }\end{array}$ & 0 & & 0 & & 1 & Matthews et al. (2014) & 1 \\
\hline $\begin{array}{l}\text { Journal of Consumer } \\
\text { Marketing }\end{array}$ & 0 & & 0 & & 1 & Albert and Merunka (2013) & 1 \\
\hline $\begin{array}{l}\text { Journal of Customer } \\
\text { Behaviour }\end{array}$ & 0 & & 0 & & 1 & Shuv-Ami (2012) & 1 \\
\hline $\begin{array}{l}\text { Journal of Economics and } \\
\text { Business }\end{array}$ & 0 & & 0 & & 1 & Mathew et al. (2012) & 1 \\
\hline \begin{tabular}{|l} 
Journal of International \\
Consumer Marketing
\end{tabular} & 0 & & 1 & Phau and Cheong (2009) & 0 & & 1 \\
\hline $\begin{array}{l}\text { Journal of International } \\
\text { Marketing }\end{array}$ & 0 & & 0 & & 1 & Eisingerich and Rubera (2010) & 1 \\
\hline Journal of Marketing Research & 1 & Ahluwalia et al. (2000) & 0 & & 0 & & 1 \\
\hline $\begin{array}{l}\text { Journal of Public Policy and } \\
\text { Marketing }\end{array}$ & 0 & & 1 & Ashley and Leonard (2009) & 0 & & 1 \\
\hline Journal of Strategic Marketing & 1 & Amine (1998) & 0 & & 0 & & 1 \\
\hline Management Decision & 0 & & 0 & & 1 & Hur et al. (2011) & 1 \\
\hline Qualitative Market Research & 0 & & 0 & & 1 & Papista and Dimitriadis (2012) & 1 \\
\hline $\begin{array}{l}\text { The Marketing Management } \\
\text { Journal }\end{array}$ & 0 & & 0 & & 1 & Srivastava and Owens (2010) & 1 \\
\hline TOTAL & 12 & & 28 & & 58 & & 98 \\
\hline
\end{tabular}


Figure 1. Elimination Process of the Articles

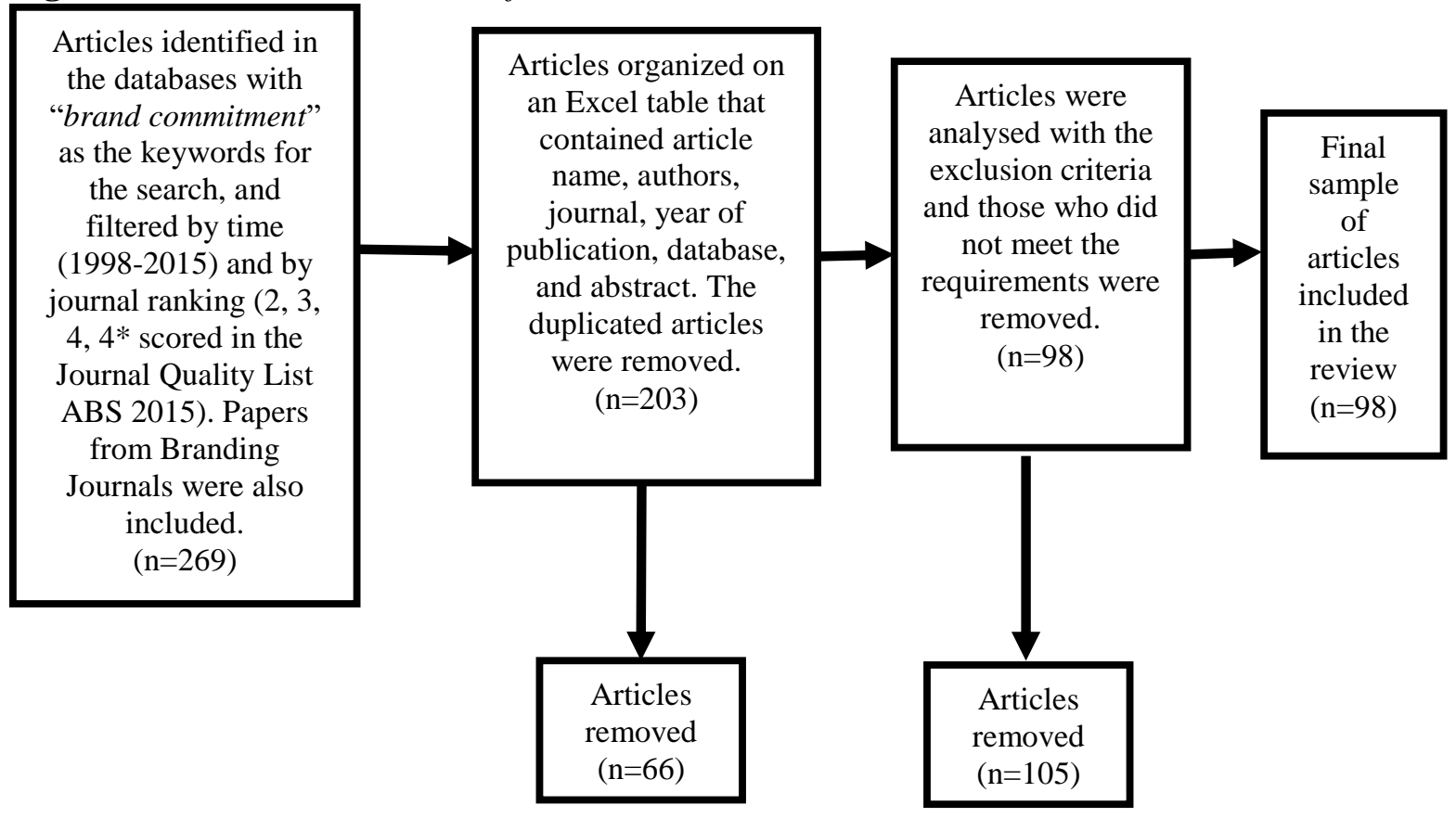

The third step of the systematic review was the data extraction process. A spreadsheet was used as a proforma. The proforma included the article title, the name of the author(s), publishing year, journal, abstract, definitions, antecedents, perspectives, dimensions, findings, and important facts. The extracted data resulted in a 45 pages document, which was the input to conduct the data synthesis. The analysis of the data was conducted considering the conceptual similarities and differences between the various definitions of brand commitment, the frequency by which the construct is explained by its dimensions, and the conceptual closeness of brand commitment with other constructs.

\section{Analysis of the Literature}

\section{Analysis of the Sample}

The papers included in this systematic literature review have specific characteristics in terms of the origin and the nature of the sample, as well as the nature of the focal object of the research. Research findings from the so called developed countries dominate research on brand commitment. Almost half of the papers were based on data from the United Stated (44 articles - 45\%), followed by France (6 articles - 6\%) and the United Kingdom (4 articles - 4\%). In terms of sampling different approaches were also used. Most of the work on brand commitment (53 articles - 54\%) had consumers as the research subjects, while 
there is relatively limited use of student samples (29 articles - 30\%). The other 16 articles $(16 \%)$ were literature reviews or had companies, voters or residents as the research subjects. Finally the majority of the research was focusing goods, since in 52 articles (53\%), brands of goods were used as the focus, while 19 articles (19\%) focused on services brands. There were also 18 articles (18\%) that used brands of goods and services simultaneously. The other 9 articles $(9 \%)$ were literature reviews or reported a specific situation or a way of living.

\section{Definitions of Brand Commitment}

A frequently used definition found in the literature states that brand commitment is the desire of the customer to maintain a valued relationship with a brand due to a previous satisfactory interaction with it (e.g. Hsiao et al., 2015; Jones et al., 2010; Mathew et al., 2012). Commitment is a key relational construct that encourages each of the parties involved to work at maintaining the relationship, to avoid alternative relations with other parties, and to reduce the perception of risk (Chaudhuri and Holbrook, 2002). Committed customers want to continue the valued relationship with the brand in the long-term by re-using, rebuying and re-patronising (Shuv-Ami, 2012), and they have the confidence that the functional and affective benefits from maintaining the relationship are greater than the benefits from ending it (Hur et al., 2011). The importance of brand commitment is recognized in the literature, as the construct is considered to be a significant predictor of purchase intentions (Ilicic and Webster, 2014). Also, commitment plays a protective role for the brand (Raju et al., 2009), as it attenuates consumers' response to negative information about the preferred brand (Germann et al., 2014), increases their resistance to competing brands' switching inducement (Srivastava and Owens, 2010), and reduces the size of the consideration set (Raju and Unnava, 2005).

One of the most profound differences in the definitions of brand commitment concerns its attitudinal or attitudinal and behavioural nature. While for some authors (e.g. Srivastava and Owens, 2010), brand commitment is an attitudinal disposition, others (e.g. Ashley and Leonard, 2009) consider the construct to be both, attitudinal and behavioural. Table 4 shows nine definitions of brand commitment found when conducting the systematic literature review. Forty-seven of the ninety-eight articles analysed presented a definition of brand commitment. The table is organized from the greater to the lower number of citations of each definition. The references are also shown in chronological order. 
Table 4. Definitions of Brand Commitment

No Definition and Reference(s)

1 Brand commitment is an attachment feeling resulting from a previous satisfactory interaction with a brand, which will drive the consumer to use the brand over time and withstand changes, creating an important and valuable relationship with it.

Hsiao et al. (2015); Germann et al. (2014); Kemp et al. (2014); Sahagun and Vasquez-Parraga (2014); Eisend and Stokburger-Sauer (2013); Albert and Merunka (2013); Park et al. (2013); Aradhita (2012); Batra et al. (2012); Magnoni and Roux (2012); Mathew et al. (2012); Shuv-Ami (2012); Sung et al. (2012); Belaid and Behi (2011); Johnson et al. (2011); Tsai (2011); Jones et al. (2010); Raju et al. (2009b); Sung and Campbell (2009); Desai and Raju (2007); Fullerton (2005); Escalas and Bettman (2003)

2 Brand commitment is the economic, emotional and psychological connection that a consumer may have towards a brand, with the expectation to create a long-term relationship.

Chang and Wu (2014); Kemp et al. (2014); Papista and Dimitriadis (2012); Iglesias et al. (2011); Sung and Choi (2010); Heere and Dickson (2008); Ahluwalia et al. (2000); Warrington and Shim (2000)

3 Brand commitment is an emotional investment from a customer towards a brand. It includes feelings of loyalty and the expectation to obtain emotional and functional benefits from the brand.

Danes et al. (2012); Hur et al. (2011); Zhang and Bloemer (2011); Pillai and Goldsmith (2008)

$4 \quad$ Brand commitment is a pledge of continuity given from one party to another, considering the sacrifice made by each party if the relationship ends and forsaking alternative options.

Louis and Lombart (2010); Evanschitzky et al. (2006); Agrawal and Maheswaran (2005); Gustafsson et al. (2005)

5 Brand commitment represents the strength of the relationship between a consumer and a brand, making the preferred brand the only acceptable choice to purchase.

Albert et al. (2013); Tuškej et al. (2013); Magnoni and Roux (2012)

6 Brand commitment is the link between the customer self and a brand, where the customer thinks that the preferred brand is an integral part of his life.

Walsh et al. (2010); Raju et al. (2009a)

7 Brand commitment is the attitudinal and behavioural disposition a consumer may have toward a certain brand, resulting in a higher probability of purchasing that brand over alternative choices.

Ashley \& Leonard (2009); Chaudhuri \& Holbrook (2002)

$8 \quad$ Brand commitment represents the degree to which the consumer is attitudinally loyal to a brand.

Srivastava \& Owens (2010)

$9 \quad$ Brand commitment is the enduring attitude or desire for a preferred brand. Lacey (2007) 
Some similarities and unique features can be observed in the nine definitions of brand commitment. Table 5 summarises the common points and the unique features of the presented definitions of the construct.

Table 5. Similarities and Unique Features of the Definitions of Brand Commitment

\begin{tabular}{|c|c|}
\hline Definitions of brand commitment & \\
\hline Similarities & Unique features \\
\hline $\begin{array}{l}\text { Emotional or attitudinal nature of the } \\
\text { construct: } \\
\text { - Attachment feeling (definition 1) } \\
\text { - Emotional connection (definition 2) } \\
\text { - Emotional investment (definition 3) } \\
\text { - Attitudinal disposition (definition 7) } \\
\text { - Enduring attitude (definition 9) }\end{array}$ & $\begin{array}{l}\text { Brand commitment includes feelings of } \\
\text { loyalty (definition 3) }\end{array}$ \\
\hline $\begin{array}{l}\text { Long-term nature of the construct: } \\
\text { - Key in the creation of an important and } \\
\text { valuable relationship with the brand over } \\
\text { time (definition 1) } \\
\text { - Committed consumers have the } \\
\text { expectation to create a long-term } \\
\text { relationship with the brand (definition 2) } \\
\text { - A pledge of continuity (definition 4) } \\
\text { - Represents the strength of a consumer- } \\
\text { brand relationship (definition 5) }\end{array}$ & $\begin{array}{l}\text { Brand commitment is the attitudinal } \\
\text { dimension of loyalty (definition } 8 \text { ) }\end{array}$ \\
\hline $\begin{array}{l}\text { Purchase and use of the brand over time as } \\
\text { an important outcome of brand } \\
\text { commitment: } \\
\text { - Brand commitment will drive the } \\
\text { consumer to use the brand over time } \\
\text { (definition 1) } \\
\text { - Brand commitment makes the preferred } \\
\text { brand the only acceptable choice to } \\
\text { purchase (definition 5) } \\
\text { - As a result of brand commitment, there } \\
\text { is a higher probability of purchasing the } \\
\text { preferred brand (definition 7) }\end{array}$ & $\begin{array}{l}\text { Brand commitment is an attitudinal as well } \\
\text { as a behavioural disposition (definition } 7 \text { ) }\end{array}$ \\
\hline & $\begin{array}{l}\text { Brand commitment is the link between the } \\
\text { consumer self and the brand (definition } 6 \text { ) }\end{array}$ \\
\hline
\end{tabular}

In summary, a generally accepted view of brand commitment states that the construct is an attachment or emotional feeling consumers have towards a preferred brand with the expectation to create a long-term relationship with it, and that drives them to purchase and use the brand over time. Alternative views affirm that brand commitment is not only attitudinal, but also behavioural, that is the 
attitudinal component of brand loyalty, and that links the consumer self with the brand.

\section{Dimensions of Brand Commitment}

Three dimensions of brand commitment -affective, continuance or calculative, and normative commitment- are usually recognized in the marketing literature (Evanschitzky et al., 2006; Gruen et al., 2000; Jones et al., 2010). The definitions of the dimensions of brand commitment are shown in table 6 .

Table 6. Dimensions of Brand Commitment

\begin{tabular}{|c|c|c|}
\hline Dimension & Definition & References \\
\hline $\begin{array}{l}\text { Affective } \\
\text { commitment }\end{array}$ & $\begin{array}{l}\text { Emotional attachment of the } \\
\text { customer to the brand, based on his } \\
\text { or her identification with it or how } \\
\text { favourable the consumer feels } \\
\text { about the brand. Affective } \\
\text { commitment pertains to "wanting" } \\
\text { to maintain the relationship. }\end{array}$ & $\begin{array}{l}\text { Hsiao et al. (2015); Hamilton et al. (2014); } \\
\text { Kemp et al. (2014); Lariviere et al. (2014); } \\
\text { Albert and Merunka (2013); Albert et al. } \\
\text { (2013); Tuškej et al. (2013); Aradhita (2012); } \\
\text { Magnoni and Roux, (2012); Mason and } \\
\text { Simmons (2012); Shuv-Ami (2012); Tanford } \\
\text { et al. (2012); Vivek et al. (2012); Belaid and } \\
\text { Behi (2011); Iglesias et al. (2011); Tsai } \\
\text { (2011); Zhang and Bloemer (2011); Jones et } \\
\text { al. (2010); Louis and Lombart (2010); Kim et } \\
\text { al. (2008); Sweeney and Swait (2008); } \\
\text { Evanschitzky et al. (2006); Johnson et al. } \\
\text { (2006); Fullerton (2005); Gustafsson et al. } \\
\text { (2005); Hansen (2004); Chaudhuri and } \\
\text { Holbrook (2002); Amine (1998) }\end{array}$ \\
\hline $\begin{array}{l}\text { Calculative } \\
\text { (continuance) } \\
\text { commitment }\end{array}$ & $\begin{array}{l}\text { Psychological attachment based on } \\
\text { the perceived costs associated with } \\
\text { ending the relationship. Calculative } \\
\text { commitment pertains to "having" to } \\
\text { maintain the relationship. }\end{array}$ & $\begin{array}{l}\text { Hsiao et al. (2015); Hamilton et al. (2014); } \\
\text { Kemp et al. (2014); Lariviere et al. (2014); } \\
\text { Albert and Merunka (2013); Albert et al. } \\
\text { (2013); Magnoni and Roux, (2012); Mason } \\
\text { and Simmons (2012); Shuv-Ami (2012); } \\
\text { Tanford et al. (2012); Belaid and Behi (2011); } \\
\text { Iglesias et al. (2011); Tsai (2011); Zhang and } \\
\text { Bloemer (2011); Jones et al. (2010); Louis and } \\
\text { Lombart (2010); Kim et al. (2008); Sweeney } \\
\text { and Swait (2008); Evanschitzky et al. (2006); } \\
\text { Johnson et al. (2006); Fullerton (2005); } \\
\text { Gustafsson et al. (2005); Chaudhuri and } \\
\text { Holbrook (2002); Amine (1998) }\end{array}$ \\
\hline $\begin{array}{l}\text { Normative } \\
\text { commitment }\end{array}$ & $\begin{array}{l}\text { Psychological bond of the } \\
\text { consumer based on his or her sense } \\
\text { of obligation to the brand. } \\
\text { Normative commitment pertains to } \\
\text { feelings as thought consumer } \\
\text { "should" maintain the relationship. }\end{array}$ & $\begin{array}{l}\text { Hsiao et al. (2015); Lariviere et al. (2014); } \\
\text { Tuškej et al. (2013); Jones et al. (2010) }\end{array}$ \\
\hline
\end{tabular}


Twenty-eight of the ninety-eight articles included in the sample (29\%) explain brand commitment with its dimensions. Affective commitment is included in the 28 articles that consider the dimensions of the construct, calculative commitment is included in 24 articles, and normative commitment is mentioned in 4 articles. Three of the twenty-eight articles explain brand commitment with its affective dimension only, twenty-one consider the affective and calculative dimensions, three include the affective, calculative and normative dimensions, and one article explains the construct with its affective and normative dimensions.

Affective commitment relates to the psychological attachment where a selfbrand connection is created (Hsiao et al., 2015; Kemp et al., 2014). It is the emotional attachment of the customer to the brand, based on his or her identification with it (Evanschitzky et al., 2006). Affective commitment reflects the consumer's desire to maintain the relationship (Jones et al., 2010). The pillars of affective commitment are shared values, identification, and attachment (Fullerton, 2005; Gruen et al., 2000). This emotional link has positive consequences on consumer behaviour, such as retention, brand repurchase, positive word of mouth and willingness to pay a price premium (Albert and Merunka, 2013). Affective commitment develops through the degree of personal involvement of the consumer with the brand (Gustafsson et al., 2005), and explains the desire of the customer to continue the relationship in the future (Johnson et al., 2006). When measuring affective commitment, factors like the pleasure of being a customer of the brand, trust, and the presence of reciprocity in the relationship are taken into account (Gustafsson et al., 2005). Consumers who are affectively committed to a brand are less vulnerable to switch to alternative brands and are less expensive to retain (Kemp et al., 2014). Affectively committed consumers' relationship with the brand is broader because psychological emotions control the functional and economic factors, and deeper because the consumers identify themselves with the brand and become less sensitive to price or convenience (Mason and Simmons, 2012).

Continuance or calculative commitment represents a more rational, economicbased dependence on a product or brand, founded in the consumer's perception of no other attractive alternatives or too high switching costs, that make difficult to end the relationship (Evanschitzky et al., 2006; Fullerton, 2005). An important characteristic in continuance commitment is the probability of losing something that adds value to the consumer (Fullerton, 2003). For instance, in the event of brand switching, the consumer loses personality fit and cultural fit with the regular brand (Fullerton, 2005). Another important motive of calculative commitment is a notably high perceived risk from the customer during purchase or use (Belaid and Behi, 2011).

Normative commitment is the level of psychological attachment of the consumer based on his or her sense of obligation to the brand. In other words, normative commitment is a feeling of obligation to a relationship (Jones et al., 2010). Normative commitment is considered the "moral attachment" dimension of 
commitment (Lariviere et al., 2014). The sense of obligation develops from a social pressure to act in a certain manner or to meet certain behaviour standards (Jones et al., 2010). Social pressure, need for approval or motivation to comply with normative beliefs are the main characteristics of this dimension of commitment (Jones et al., 2010; Lariviere et al., 2014; Tuškej et al., 2013). Another mechanism identified as a base of normative commitment is the social norm of reciprocity (Meyer et al., 2002).

The affective dimension of brand commitment is considered to be fundamental when defining the nature of the construct. All the articles that explain brand commitment with its dimensions highlight the relevance of the affective component. Some authors (e.g. Hansen, 2004; Vivek et al., 2012) even consider the affective dimension as the only relevant to explain the construct. Calculative, or continuance commitment is also frequently found in the literature when explaining the dimensions of brand commitment, which suggests two relevant facets of the construct: the emotional and the rational. Normative commitment, on the other hand, is seldom found in the brand commitment literature, suggesting a low relevance of this dimension.

\section{Brand Commitment and other Constructs}

The relationship between brand commitment and other constructs is well documented in the literature. There are constructs that are normally used as antecedents of brand commitment, other constructs that are seen as outcomes, while some concepts considered conceptually similar to brand commitment.

\section{Brand Commitment as an Outcome}

The review identifies several antecedents of commitment (see table 7). The construct of satisfaction, defined as the overall emotional reaction to a brand purchasing and usage experience (Wang, 2002), is a well-recognized antecedent of brand commitment in the marketing literature. Customer satisfaction is a transactional driver that creates a positive emotional response to the attributes, quality, and value that a brand offers (Sahagun and Vasquez-Parraga, 2014). Satisfaction is a predictor of future consumer behaviour and it influences the opinion that the customer has about the brand (Hsiao et al., 2015). A satisfied consumer is more likely to repurchase the brand and to commit to the relationship with it. (Evanschitzky et al., 2006; Shuv-Ami, 2012; Story and Hess, 2010; Sung and Campbell, 2009; Sung and Choi, 2010). Brand commitment is stronger than customer satisfaction, as satisfaction is backward-looking and commitment is forward-looking (Wolny and Mueller, 2013). 
Table 7. Brand Commitment as an Outcome of

\begin{tabular}{|c|c|}
\hline Satisfaction & $\begin{array}{l}\text { Hsiao et al. (2015); Lariviere et al. (2014); Sahagun and Vasquez- } \\
\text { Parraga (2014); Shuv-Ami (2012); Sung and Choi (2010); Sung } \\
\text { and Campbell (2009); Evanschitzky et al. (2006); Fullerton (2005); } \\
\text { Gustafsson et al. (2005); Tax et al. (1998) }\end{array}$ \\
\hline Trust & $\begin{array}{l}\text { Kemp et al. (2014); Sahagun \& Vasquez-Parraga (2014); Albert } \\
\text { and Merunka (2013); Jahn et al. (2012); Hur et al. (2011); Louis \& } \\
\text { Lombart (2010); Story and Hess (2010); Lacey (2007); Chaudhuri } \\
\text { and Holbrook (2002); Delgado-Ballester and Munuera-Alemán } \\
\text { (2001) }\end{array}$ \\
\hline Attachment to the brand & $\begin{array}{l}\text { Hamilton et al. (2014); Ilicic and Webster (2014); Louis and } \\
\text { Lombart (2010); Amine (1998) }\end{array}$ \\
\hline Involvement & $\begin{array}{l}\text { Broderick (2007); Coulter et al. (2003); Warrington and Shim } \\
\text { (2000); Pritchard et al. (1999) }\end{array}$ \\
\hline Brand identification & $\begin{array}{l}\text { Kemp et al. (2014); Albert and Merunka (2013); Albert et al. } \\
\text { (2013) }\end{array}$ \\
\hline Brand love & Albert et al. (2013); Albert and Merunka (2013); Batra et al. (2012) \\
\hline Quality of alternatives & Sung and Choi (2010); Sung and Campbell (2009); Amine (1998) \\
\hline Perceived value & Kemp et al. (2014); Johnson et al. (2006) \\
\hline Switching costs & Hamilton et al. (2014); Lacey (2007) \\
\hline Attitude toward the brand & Kemp et al. (2014); Kim et al. (2008) \\
\hline Identification & Albert et al. (2013); Tuškej et al. (2013) \\
\hline Perceived risk/Risk aversion & Choi and Ahluwalia (2013); Amine (1998) \\
\hline Brand social responsibility & Kemp et al. (2014); Eisingerich and Rubera (2010) \\
\hline Brand affect & Hur et al. (2011); Chaudhuri and Holbrook (2002) \\
\hline Relationship investment & Sung and Choi (2010); Sung and Campbell (2009) \\
\hline Service quality & Hsiao et al. (2015) \\
\hline Referent influence & Kemp et al. (2014) \\
\hline Brand passion & Albert et al. (2013) \\
\hline Performance & Shuv-Ami (2012) \\
\hline Loyalty & Shuv-Ami (2012) \\
\hline Brand credibility & Mathew et al. (2012) \\
\hline Gender & Tifferet and Herstein (2012) \\
\hline Brand self-relevance/Self-connection & Eisingerich and Rubera (2010) \\
\hline Brand innovativeness & Eisingerich and Rubera (2010) \\
\hline Brand customer orientation & Eisingerich and Rubera (2010) \\
\hline Brand personality & Louis and Lombart (2010) \\
\hline Resistance to change & Srivastava and Owens (2010) \\
\hline Shared values & Lacey (2007) \\
\hline Confidence benefits & Lacey (2007) \\
\hline Economic value & Lacey (2007) \\
\hline Customer recognition & Lacey (2007) \\
\hline Preferential treatment & Lacey (2007) \\
\hline Ideological position & Coulter et al. (2003) \\
\hline Brand experimentation & Coulter et al. (2003) \\
\hline Information complexity & Pritchard et al. (1999) \\
\hline Volitional choice & Pritchard et al. (1999) \\
\hline Brand sensitivity & Amine (1998) \\
\hline
\end{tabular}


Trust is one of the most cited antecedents of brand commitment (e.g. Jahn et al., 2012; Lacey, 2007; Louis and Lombart, 2010). Trust is viewed as consumer's expectations that the brand can be relied on to deliver what it promises (Lacey, 2007). Customers will commit to the brand when trust is already established (Kemp et al., 2014), so customer's commitment to a brand is the consequence of his trust in it (Louis and Lombart, 2010).

Another important antecedent of commitment is attachment to the brand, which is considered as an emotional and psychological reaction where the customer feels the necessity to purchase the brand (Ilicic and Webster, 2014).

Attitude toward a brand, seen as a strong resistance to attitude change, or the behavioural disposition to maintain the established attitude (Kim et al., 2008), is also an important antecedent of brand commitment. High levels of attitude strength toward the brand lead to stronger brand commitment (Kim et al., 2008; VonRiesen et al., 2001).

\section{Brand Commitment as an Antecedent}

The evidence also shows that brand commitment has implications for other constructs. In the literature (see table 8), there are a number of studies that examine the link between brand commitment and customer retention, operationalized as repurchase intentions (Fullerton, 2005). Brand commitment, especially affective commitment, is a strong driver of repurchase intentions towards the preferred brand (Fullerton, 2005; Jones et al., 2010).

True brand loyalty is another extensively researched consequence of brand commitment (Kim et al., 2008; Mathew et al., 2012). Brand commitment, particularly its affective dimension, is a key antecedent of brand loyalty (Evanschitzky et al., 2006) that distinguishes true from spurious loyalty (Kim et al., 2008).

Committed consumers tend to recommend the preferred brand to others (Shuv-Ami, 2012). Brand commitment acts as an important antecedent of the positive word-of-mouth behaviour (Kim et al., 2008). In their research, de Matos and Rossi (2008) demonstrate that commitment is the main correlate of positive word-of-mouth.

Brand commitment, especially affective commitment, has a significant impact on consumers' acceptance of a price premium. This means that consumers' willingness to continue to buy the brand, even after price increases, is mostly motivated by affective reasons (Albert and Merunka, 2013). 
Table 8. Brand Commitment as an Antecedent of

\begin{tabular}{|l|l|}
\hline Purchase/repurchase intentions & $\begin{array}{l}\text { Shuv-Ami (2012); Hur et al. (2011); Jones et al. } \\
(2010) ; \text { Kim et al. (2008); Lacey (2007); Fullerton } \\
(2005)\end{array}$ \\
\hline $\begin{array}{l}\text { Recommendation/Positive word } \\
\text { of mouth }\end{array}$ & $\begin{array}{l}\text { Albert and Merunka (2013); Shuv-Ami (2012); Hur et } \\
\text { al. (2011); Kim et al. (2008); Amine (1998) }\end{array}$ \\
\hline Loyalty/True brand loyalty & $\begin{array}{l}\text { Mathew et al. (2012); Kim et al. (2008); Evanschitzky } \\
\text { et al. (2006) }\end{array}$ \\
\hline Overall attitude/Attitude change & Shuv-Ami (2012); Ahluwalia et al. (2000) \\
\hline $\begin{array}{l}\text { Willingness to pay a price } \\
\text { premium }\end{array}$ & Albert and Merunka (2013) \\
\hline $\begin{array}{l}\text { Consumer responses in product } \\
\text { recalls }\end{array}$ & Germann et al. (2014) \\
\hline Share of wallet (SOW) & Lariviere et al. (2014) \\
\hline Preference & Shuv-Ami (2012) \\
\hline Constructive complaint & Hur et al. (2011) \\
\hline Self-Brand connection & Kemp and Bui (2011) \\
\hline Cooperation/Co-Production & Kim et al. (2008) \\
\hline Cross-over buying & Kim et al. (2008) \\
\hline Participation & Kim et al. (2008) \\
\hline Increased Share-of-Customer & Lacey (2007) \\
\hline Advocacy intentions & Fullerton (2005) \\
\hline Customer retention & Gustafsson et al. (2005) \\
\hline Confidence in the brand & Amine (1998) \\
\hline
\end{tabular}

\section{$\underline{\text { Brand Commitment as Conceptually Similar to other Constructs }}$}

Although there are some constructs that are seen as similar to brand commitment (see table 9), the construct that is most closely conceptually related is brand loyalty. Brand loyalty has been extensively studied within the marketing discipline (Heere and Dickson, 2008), and it is considered to be one of the four components of brand equity, along with brand awareness, brand associations and perceived quality in one of the most widely used conceptualisations of brand equity (Aaker, 1991). Different authors have different approaches regarding the relation between brand loyalty and brand commitment. For some authors, brand commitment is an antecedent of brand loyalty, as it is viewed as the attachment that leads to loyalty (Evanschitzky et al., 2006). Miquel-Romero et al. (2014) state that brand commitment plays a mediating role between satisfaction, trust, and loyalty, as satisfaction influences trust, trust influences commitment, and commitment influences loyalty. Other authors consider brand commitment to be a consequence of brand loyalty. Shuv-Ami (2012) offers a theoretical conceptualisation of brand commitment, in which loyalty is linked with the emotional attachment and involvement is linked with the engagement attachment. Together, they form the affective component of brand commitment, and the 
calculative component is represented by performance (evaluation attachment) and satisfaction (experiential attachment). A commonly found approach in the literature states that the presence of brand commitment is a necessary requisite in order to achieve true brand loyalty (Kim et al., 2008). The absence of brand commitment results in spurious loyalty, composed by a spurious, unstable attitude incapable to influence subsequent behaviours, and by spurious, unpredictable behaviours (Kim et al., 2008). Beyond the desire of reacquiring a preferred brand, a consumer also can desire to be committed to it (Oliver, 1999).

For other authors, brand commitment and brand loyalty are conceptually similar constructs (e.g. Thomson et al., 2005), as one is part of the definition of the other. For example, Hamilton et al. (2014) and Matthews et al. (2014) define loyalty as a profound commitment to repurchase and keep favouring a preferred brand in the future. From this point of view, commitment is a part of loyalty, as loyalty is conceptualized as "a long-term, committed, and affect-laden partnership" (Fournier, 1998: page 343). This approach focuses on the importance of brand emotional value or emotional attachment and trust in building a long-term relationship (Matthews et al., 2014; Thomson et al., 2005).

The concept of brand loyalty has been researched using two approaches: the stochastic and the determinist (Odin et al., 2001). In the stochastic approach, loyalty is considered a merely behavioural construct -simply repeat buying-, with the constraint for the owner of the brand of not being capable of knowing the real cause of loyalty (Dick \& Basu, 1994; Odin et al., 2001). In the determinist approach, loyalty is considered more as an attitude, where the focus is the consumer's psychological commitment in the purchase, and not necessarily his purchase behaviour (Odin et al., 2001). Focusing on only one approach would lead to spurious loyalty, defined as unpredictable attitudes that do not influence behaviour or repeat purchasing behaviour with low sensitivity towards the brand, or inertial purchasing (Kim et al., 2008). In order to integrate the attitudinal and behavioural components in the definition of brand loyalty, the construct is considered as "the biased (i.e., non-random) behavioural response (i.e., purchase) expressed over time by some decision-making units with respect to one or more alternative brands out of a set of such brands, which is a function of psychological (decision making, evaluative) processes" (Jacoby and Chestnut, 1978: page 80). Loyalty has also been defined as "the strength of the relationship between an individual's relative attitude and repeat patronage" (Dick and Basu, 1994: page 99), or a deeply held intent to rebuy or re-patronize a brand in the future (ElManstrly \& Harrison, 2013; Oliver, 1999). This means that brand loyalty is a behavioural answer to an evaluative psychological process (Odin et al., 2001).

The literature argues that the process of building loyalty consists of four phases: 1) cognitive loyalty (based on brand belief); 2) affective loyalty (cognition and affect. A liking or attitude toward the brand has developed); 3) conative loyalty (behavioural intentions influenced by repeated episodes of positive affect toward the brand. Brand commitment is needed to repurchase); 4) action loyalty 
(intentions converted into actions, readiness to act, accompanied by the desire to overcome the obstacles that might prevent the act) (El-Manstrly and Harrison, 2013; Matthews et al., 2014; Oliver, 1999). Readiness to act is analogous to the deeply held commitment to re-buy or re-patronize a preferred brand in the future, so, in order for 'ultimate loyalty' to happen, commitment must be present. The action loyal consumer has a deep commitment to repurchase (Oliver, 1999). As stated by Oliver (1999), commitment is a pledge of relational continuity that goes beyond conative and action loyalty, because it is found at a conscious level, and is an objective in and of itself.

In synthesis, brand commitment is a key pro-relational construct that differentiates true brand loyalty from other repeat purchase behaviours like habit, inertia or spurious loyalty (Srivastava and Owens, 2010), and acts as the mediator between brand satisfaction, advocacy intentions and repurchase intentions (Fullerton, 2005).

There are other constructs that are seen as conceptually similar to brand commitment, but there is less support for these arguments. Wolny and Mueller (2013) define brand involvement, or brand commitment, as positive feelings of attachment to a brand that enable the individual to withstand changes. For the authors, the two concepts are conceptually similar. Focusing on a different construct, Papista and Dimitriadis (2012) state that consumers find difficult to recognise that human emotions like love and passion can be developed for brands. For this reason, the authors consider the dimensions of love and passion in the consumer-brand relationship quality to be similar to the affective commitment construct.

Table 9. Brand Commitment as Conceptually Similar to

\begin{tabular}{|l|l|}
\hline Brand loyalty & $\begin{array}{l}\text { Hamilton et al. (2014); Matthews et al. (2014); Thomson et } \\
\text { al. (2005) }\end{array}$ \\
\hline Brand involvement & Wolny and Mueller (2013) \\
\hline Brand passion & Papista and Dimitriadis (2012) \\
\hline
\end{tabular}

\section{Conceptual Evolution of Brand Commitment}

Kiesler (1971) defined brand commitment as the pledging of a subject to behavioural acts, viewing the construct in attitudinal and behavioural terms. Later, Lastovicka and Gardner (1979) defined the concept as the emotional or psychological attachment to a brand, viewing brand commitment as an attitudinal construct. In the same line, Traylor (1981) considered brand commitment to be an attitudinal concept. Martin and Goodell (1991) conceptualised brand commitment as having attitudinal and behavioural dimensions. More recently, the concept of brand commitment shows stability in its definition, as the desire to create and maintain a valued relationship with a brand (e.g. Desai and Raju, 2007; Hsiao et 
al., 2015; Warrington and Shim, 2000), but variability in its relation with other constructs. Beginning the twenty-first century, it is recurrent the argument in the literature that an effort from the parts is necessary to create and maintain the relationship over time. This means that for both, the customer and the brand, some sacrifices have to be made in order to maintain the relationship (e.g. Agrawal and Maheswaran, 2005; Evanschitzky et al., 2006; Gustafsson et al., 2005). From 2007 to 2010 , brand commitment appeared to be more related to customer personality, self-identification with the brand and shared values. (e.g. Raju et al., 2009; Srivastava and Owens, 2010; Walsh et al., 2010;). More recently, from 2011 to 2015, researchers view brand commitment as an emotional investment where the brand becomes the only acceptable choice to purchase, and the customer expects to obtain emotional and functional benefits from it (Albert et al., 2013; Danes et al., 2012; Hur et al., 2011; Magnoni and Roux, 2012;Tuškej et al., 2013; Zhang and Bloemer, 2011). It is also important to highlight that explaining brand commitment with its three dimensions -affective, calculative and normative- is a recent practice, since the majority $(68 \%)$ of the articles included in this review conceptualising brand commitment with its dimensions correspond to the 20102015 time period.

There are different perspectives in the literature over time regarding the relationship between brand commitment and brand loyalty. Although there is not a clear chronological trend for each perspective, it can be observed a shift from brand commitment being considered the attitudinal component of brand loyalty (e.g. Odin et al., 2001), to brand commitment and brand loyalty being considered conceptually similar (e.g. Raju and Unnava, 2005), and to brand commitment being considered an antecedent of true brand loyalty (e.g. Lariviere et al., 2014).

\section{Discussion}

As stated in this systematic literature review, the relevance of brand commitment is acknowledged by academics and practitioners. A recent interest in the research of the construct is evidenced by the fact that more than half of the journal articles resulting from an unfiltered search in the EBSCO database from 1960 to 2015 were published after 2010. However, as this research shows, brand commitment's multiple definitions and dimensions, as well as the substantive content that overlaps with other concepts, make it difficult to conceptualise and operationalise the construct.

Most of the research on brand commitments published in the higher ranked marketing journals has been contacted in certain countries. There is a need for more research on brand commitment in countries outside the developed countries such as the US, the UK and France that seem to have the most reported results. 
There is no agreement on the exact nature of the concept, since researchers define brand commitment in many alternative ways. This lack of consensus generates confusion amongst researchers, as they approach the construct using their own variations of definitions and conceptual models. Similarities, as well as unique features of the different definitions of brand commitment were identified to define the construct as the attachment or emotional feeling consumers have towards a preferred brand with the expectation to create a long-term relationship with it, and that drives them to purchase and use the brand over time. This definition views brand commitment as an attitudinal connection, in the same research line that Belaid and Behi (2011) and Germann et al. (2014), and contrary to the research stream that considers the construct as an attitudinal and behavioural disposition (Ashley and Leonard, 2009; Chaudhuri and Holbrook, 2002). The presented definition is aligned with the researchers that focus on the attitudinal dimension of brand commitment -i.e. it is an emotional investment- and also consider the construct's positive behavioural outcomes for the brand -i.e. for committed consumers, the preferred brand is the only acceptable choice to purchase-(Albert et al., 2013; Tuškej et al., 2013).

This review highlights the relevance of the affective component of brand commitment. All the reviewed articles that explain the construct with its dimensions -twenty-nine percent of the articles included in the samplerecognised the relevance of the affective component to explain the nature of the construct. Some authors (e.g. Hansen, 2004; Vivek et al., 2012) consider the affective dimension as the only relevant to explain brand commitment. This is coherent with the definition of the construct as an attachment or emotional feeling, as affective commitment pertains to "wanting" to maintain the relationship with the brand in the long term (Jones et al., 2010).

One important aspect outlined by this systematic literature review is the relevance of the affective dimension of brand commitment and its role in differentiating true brand loyalty from inertia or spurious loyalty. As stated by Oliver (1999), brand commitment has to be present in order for 'ultimate loyalty' to happen. Thus, managers could focus on enhancing the affective attributes of the brand to increase their base of truly loyal customers.

Important antecedents and outcomes of brand commitment are highlighted in this research. While two powerful antecedents of brand commitment recognised in the review are satisfaction (Sung and Choi, 2010) and trust (Lacey, 2007), it is emphasised on the construct's capacity to accurately predict repurchase intentions (Jones et al., 2010) and positive word-of-mouth (Albert and Merunka, 2013). Among the most relevant antecedents of brand commitment are trust (Jahn et al., 2012; Lacey, 2007) and attachment to the brand (Ilicic and Webster, 2014). Commitment acts as the mediator between brand satisfaction and repurchase and advocacy intentions (Fullerton, 2005). Brand commitment is also a trustful predictor of positive word-of-mouth (de Matos and Rossi, 2008; Kim et al., 2008) and acceptance of a price premium (Albert and Merunka, 2013). This means, from 
a managerial perspective, that putting efforts on increasing consumers' satisfaction and trust towards the brand impacts positively their level of commitment, which results in increased repurchase intentions and positive word-of-mouth. The consequences for managers are higher sales and improved business growth.

Also, the systematic literature review outlines the protective role that commitment plays for the brand. As stated by Ahluwalia et al. (2000), committed consumers are expected to question the validity of negative information about the preferred brand. This, in turn, relates to market share and advertising efficiency (Ahluwalia et al., 2000; Chaudhuri and Holbrook, 2002). Thus, for managers, investing in enhancing brand commitment, results in the long-term preference of their brand over other competing options.

In the analysis of brand commitment with other constructs, this review helps to clarify the differences between commitment and loyalty. Although some authors (e.g. Matthews et al., 2014; Thomson et al., 2005) consider the two constructs to be conceptually similar, this systematic literature review reveals a closer association of commitment with the deterministic approach of loyalty, in the same research line that Odin et al. (2001). The presence of brand commitment is necessary for a successful process of building loyalty, as described by El-Manstrly and Harrison (2013). Furthermore, the conceptualisation of brand commitment as an attitudinal construct described in this research sets the basis to differentiate it from brand loyalty. The presence of affective commitment is crucial to differentiate true brand loyalty from spurious behaviours like inertia or habit (Srivastava and Owens, 2010).

This study is not free of shortcomings. Regarding the inclusion criteria, the use of articles included in journals of marketing $2,3,4$, and $4^{*}$ included in the ABS 2015 list to conduct the review can limit the generality and inclusivity of the analysis, as valuable literature on brand commitment could have been left out. The other factors considered in the inclusion criteria, such as language, the consideration of academic publications only, and a maximum number of years of published for the papers of the sample, could also lead to leave out relevant work on the topic. When conducting the systematic review of the brand commitment literature, it became clear the connexion of the construct with brand loyalty. Although brand loyalty has been extensively studied, the real relation between this construct and brand commitment is still ambiguous. For instance, it seems evident from the literature review that the four phases of the process of building brand loyalty (El-Manstrly and Harrison, 2013) are closely related, and could be replaced with the described dimensions of brand commitment. Future research could focus on the causes and consequences of the relationship between the two constructs, considering different contexts and product categories. Another interesting avenue for future research would be the relevance of brand commitment in a business to business environment. All the articles included in the sample to conduct the systematic literature review researched brand commitment in a business to 
consumer setting. Further studies might emphasise the importance of brand commitment in business to business relationships.

\section{References}

Aaker, D. A. (1991). Managing Brand Equity. New York: The Free Press.

Agrawal, N., and Maheswaran, D. (2005). The Effects of Self-Construal and Commitment on Persuasion. Journal of Consumer Research, 31(4), 841-849.

Ahluwalia, R. (2000). Examination of Psychological Processes Underlying Resistance to Persuasion. Journal of Consumer Research, 27, 217-232.

Ahluwalia, R., Burnkrant, R. E., and Unnava, H. R. (2000). Consumer Response to Negative Publicity: The Moderating Role of Commitment. Journal of Marketing Research, 37(2), 203-214.

Aitken, R., and Campelo, A. (2011). The four Rs of place branding. Journal of Marketing Management, 27(9-10), 913-933.

Albert, N., and Merunka, D. (2013). The role of brand love in consumer-brand relationships. Journal of Consumer Marketing, 30(3), 258-266.

Albert, N., Merunka, D., and Valette-Florence, P. (2013). Brand passion: Antecedents and consequences. Journal of Business Research, 66(7), 904-909.

Allaway, A. W., Huddleston, P., Whipple, J., and Ellinger, A. E. (2011). Customer-based brand equity, equity drivers, and customer loyalty in the supermarket industry. Journal of Product \& Brand Management, 20(3), 190-204.

Amine, A. (1998). Consumers' true brand loyalty: the central role of commitment. Journal of Strategic Marketing, 6, 305-319.

Aradhita, A. (2012). Impacts of perceived brand relationship orientation on attitudinal loyalty: An application to strong brands in the packaged goods sector (Case study: Häagen-Dazs Indonesia). European Journal of Marketing, 46(11), 1602-1627.

Ashley, C., and Leonard, H. A. (2009). Betrayed by the Buzz? Covert Content and Consumer-Brand Relationships. Journal of Public Policy \& Marketing, 28(2), 212220.

Batra, R., Ahuvia, A., and Bagozzi, R. P. (2012). Brand Love. Journal of Marketing, 76(2), 1-16.

Beatty, S. E., and Kahle, L. R. (1988). Alternative Hierarchies of the Attitude-Behavior Relationship: The Impact of Brand Commitment and Habit. Journal of the Academy of Marketing Science, 16(2), 1-10.

Belaid, S., and Behi, A. T. (2011). The role of attachment in building consumer-brand relationships: an empirical investigation in the utilitarian consumption context. Journal of Product \& Brand Management, 20(1), 37-47.

Broderick, A. J. (2007). A cross-national study of the individual and national-cultural nomological network of consumer involvement. Psychology \& Marketing, 24(4), 343-374.

Brodie, R. J., Ilic, A., Juric, B., and Hollebeek, L. (2013). Consumer engagement in a virtual brand community: An exploratory analysis. Journal of Business Research, 66(1), 105-114.

Carroll, B. A., and Ahuvia, A. C. (2006). Some antecedents and outcomes of brand love. 
Marketing Letters, 17(2), 79-89.

Chang, H. H., and Wu, L. H. (2014). An examination of negative e-WOM adoption: Brand commitment as a moderator. Decision Support Systems, 59, 206-218.

Chaudhuri, A., and Holbrook, M. B. (2002). Product-class effects on brand commitment and brand outcomes: The role of brand trust and brand affect. Journal of Brand Management, 10(1), 33-58.

Choi, B., and Ahluwalia, R. (2013). Determinants of brand switching: the role of consumer inferences, brand commitment, and perceived risk. Journal of Applied Social Psychology, 43, 981-991.

Cohen, J. B., and Houston, M. J. (1972). Cognitive Consequences of Brand Loyalty. Journal of Marketing Research, IX, 97-99.

Coulter, R. A., Price, L. L., and Feick, L. (2003). Rethinking the Origins of Involvement and Brand Commitment: Insights from Postsocialist Central Europe. Journal of Consumer Research, 30(September), 151-169.

Danes, J. E., Hess, J. S., Story, J. W., and Vorst, K. (2012). On the validity of measuring brand images by rating concepts and free associations. Journal of Brand Management, 19(4), 289-303.

de Matos, C. A., and Rossi, C. A. V. (2008). Word-of-mouth communications in marketing: A meta-analytic review of the antecedents and moderators. Journal of the Academy of Marketing Science, 36(4), 578-596.

Delgado-Ballester, E., and Munuera-Alemán, J. L. (2001). Brand trust in the context of consumer loyalty. European Journal of Marketing, 35(11/12), 1238-1258.

Desai, K. K., and Raju, S. (2007). Adverse Influence of Brand Commitment on Consideration of and Preference for Competing Brands. Psychology \& Marketing, 24(7), 595-614.

Dick, A. S., and Basu, K. (1994). Customer Loyalty: Toward an Integrated Conceptual Framework. Journal of the Academy of Marketing Science, 22(2), 99-113.

Eisend, M., and Stokburger-Sauer, N. E. (2013). Brand personality: A meta-analytic review of antecedents and consequences. Marketing Letters, 24(3), 205-216.

Eisingerich, A. B., and Rubera, G. (2010). Drivers of Brand Commitment: A CrossNational Investigation. Journal of International Marketing, 18(2), 64-79.

El-Manstrly, D., and Harrison, T. (2013). A critical examination of service loyalty measures. Journal of Marketing Management, 29(15/16), 1834-1861.

Escalas, J. E., and Bettman, J. R. (2003). You Are What They Eat: The Influence of Reference Groups on Consumers' Connections to Brands. Journal of Consumer Psychology, 13(3), 339-348.

Evanschitzky, H., Iyer, G. R., Plassmann, H., Niessing, J., and Meffert, H. (2006). The relative strength of affective commitment in securing loyalty in service relationships. Journal of Business Research, 59(12), 1207-1213.

Ferrand, A., Robinson, L., and Valette-Florence, P. (2010). The Intention-to-Repurchase Paradox: A Case of the Health and Fitness Industry. Journal of Sport Management, $24,83-105$.

Fournier, S. (1998). Consumers and Their Brands: Developing Relationship Theory in Consumer Research. Journal of Consumer Research, 24(1), 343-373.

Fullerton, G. (2003). When does commitment lead to loyalty? Journal of Service Research, 5(4), 333-344.

Fullerton, G. (2005). The Impact of Brand Commitment on Loyalty to Retail Service 
Brands. Canadian Journal of Administrative Sciences, 22(2), 97-110.

Germann, F., Grewal, R., Ross, W. T., and Srivastava, R. K. (2014). Product recalls and the moderating role of brand commitment. Marketing Letters, 25(2), 179-191.

Glynn, M. S., Brodie, R. J., and Motion, J. (2012). The benefits of manufacturer brands to retailers. European Journal of Marketing, 46(9), 1127-1149.

Grossbart, S., Gill, J., and Laczniak, R. N. (1987). Influence of Brand Commitment and Claim Strategy on Consumer Attitudes. Advances in Consumer Research, 14(1), 510-513.

Gruen, T. W., Summers, J. O., and Acito, F. (2000). Relationship Marketing Activities, Commitment, and Membership Behaviors in Professional Associations. Journal of Marketing, 64(July), 34-49.

Gustafsson, A., Johnson, M. D., and Roos, I. (2005). The Effects of Customer Satisfaction, Relationship Commitment Dimensions, and Triggers on Customer Retention. Journal of Marketing, 69, 210-218.

Hamilton, R. W., Thompson, D. V., Arens, Z. G., Blanchard, S. J., Häubl, G., Kannan, P. K., ... Thomas, M. (2014). Consumer substitution decisions: An integrative framework. Marketing Letters, 25(3), 305-317.

Han, S., and Sung, H. (2008). Industrial brand value and relationship performance in business markets - A general structural equation model. Industrial Marketing Management, 37(7), 807-818.

Hansen, H. (2004). Brand Extension Evaluations: Effects of Affective Commitment, Involvement, Price Consciousness and Preference for Bundling in the Extension Category. Advances in Consumer Research, 31, 375-381.

Heere, B., and Dickson, G. (2008). Measuring Attitudinal Loyalty: Separating the Terms of Affective Commitment and Attitudinal Loyalty. Journal of Sport Management, 22, 227-239.

Horppu, M., Kuivalainen, O., Tarkiainen, A., and Ellonen, H. (2008). Online satisfaction, trust and loyalty, and the impact of the offline parent brand. Journal of Product \& Brand Management, 17(6), 403-413.

Hsiao, C., Shen, G. C., and Chao, P. (2015). How does brand misconduct affect the brand-customer relationship? Journal of Business Research, 68(4), 862-866.

Hur, W., Ahn, K., and Kim, M. (2011). Building brand loyalty through managing brand community commitment. Management Decision, 49(7), 1194-1213.

Iglesias, O., Singh, J. J., and Batista-Foguet, J. M. (2011). The role of brand experience and affective commitment in determining brand loyalty. Journal of Brand Management, 18(8), 570-582.

Ilicic, J., and Webster, C. M. (2014). Investigating consumer-brand relational authenticity. Journal of Brand Management, 21(4), 342-363.

Jacoby, J. (1971). A Model of Multi-Brand Loyalty. Journal of Advertising Research, 11, $25-31$.

Jacoby, J., and Chestnut, R. W. (1978). Brand Loyalty: Measurement and Management. New York: John Wiley.

Jahn, S., Gaus, H., and Kiessling, T. (2012). Trust, Commitment, and Older Women: Exploring Brand Attachment Differences in the Elderly Segment. Psychology \& Marketing, 29(6), 445-457.

Johnson, A. R., Matear, M., and Thomson, M. (2011). A Coal in the Heart: SelfRelevance as a Post-Exit Predictor of Consumer Anti-Brand Actions. Journal of 
Consumer Research, 38(1), 108-125.

Johnson, M. D., Herrmann, A., and Huber, F. (2006). The Evolution of Loyalty Intentions. Journal of Marketing, 70(April), 122-132.

Jones, T., Fox, G. L., Taylor, S. F., and Fabrigar, L. R. (2010). Service customer commitment and response. Journal of Services Marketing, 24(1), 16-28.

Kemp, E., and Bui, M. (2011). Healthy brands: establishing brand credibility, commitment and connection among consumers. Journal of Consumer Marketing, 28(6), 429-437.

Kemp, E., Jillapalli, R., and Becerra, E. (2014). Healthcare branding: developing emotionally based consumer brand relationships. Journal of Services Marketing, $28(2), 126-137$.

Kiesler, C. A. (1971). The Psychology of Commitment: Experiments Linking Behavior to Belief (Social Psychology Monographs). San Diego, CA: Academic Press Inc.

Kim, J., Morris, J. D., and Swait, J. (2008). Antecedents of True Brand Loyalty. Journal of Advertising, 37(2), 99-117.

Kim, J. W., Choi, J., Qualls, W., and Han, K. (2008). It takes a marketplace community to raise brand commitment: the role of online communities. Journal of Marketing Management, 24(3-4), 409-431.

Lacey, R. (2007). Relationship Drivers of Customer Commitment. Journal of Marketing Theory and Practice, 15(4), 315-333.

Lariviere, B., Keiningham, T. L., Cooil, B., Aksoy, L., and Malthouse, E. C. (2014). A longitudinal examination of customer commitment and loyalty. Journal of Service Management, 25(1), 75-100.

Lastovicka, J. L., and Gardner, D. M. (1979). Components of Involvement. In J. C. Maloney \& B. Silverman (Eds.), Attitudes Play for High Stackers (pp. 53-73). Chicago: American Marketing Association.

Leigh, T. W., Peters, C., and Shelton, J. (2006). The Consumer Quest for Authenticity: The Multiplicity of Meanings Within the MG Subculture of Consumption. Journal of the Academy of Marketing Science, 34(4), 481-493.

Louis, D., and Lombart, C. (2010). Impact of brand personality on three major relational consequences (trust, attachment, and commitment to the brand). Journal of Product \& Brand Management, 19(2), 114-130.

Magnini, V. P. (2011). The implications of company-sponsored messages disguised as word-of-mouth. Journal of Services Marketing, 25(4), 243-251.

Magnoni, F., and Roux, E. (2012). The impact of step-down line extension on consumerbrand relationships: A risky strategy for luxury brands. Journal of Brand Management, 19(7), 595-608.

Martin, C. L., and Goodell, P. W. (1991). Historical, Descriptive and Strategic Perspectives on the Construct of Product Commitment. European Journal of Marketing, 25(1), 53-60.

Mason, C., and Simmons, J. (2012). Are they being served? Linking consumer expectation, evaluation and commitment. Journal of Services Marketing, 26(4), 227237.

Mathew, V., Thomas, S., and Injodey, J. I. (2012). Direct and Indirect Effect of Brand Credibility, Brand Commitment and Loyalty Intentions on Brand Equity. Journal of Economics and Business, 10(2), 73-82.

Matthews, D. R., Son, J., and Watchravesringkan, K. (2014). An exploration of brand 
equity antecedents concerning brand loyalty: A cognitive, affective, and conative perspective. Journal of Business and Retail Management Research, 9(1), 26-39.

Meyer, J. P., Stanley, D. J., Herscovitch, L., and Topolnytsky, L. (2002). Affective, Continuance, and Normative Commitment to the Organization: A Meta-analysis of Antecedents, Correlates, and Consequences. Journal of Vocational Behavior, 61(1), $20-52$.

Michaelidou, N. (2012). A typology of consumers' variety-seeking disposition based on inherent needs. Journal of Marketing Management, 28(5-6), 676-694.

Miquel-Romero, M. J., Caplliure-Giner, E. M., and Adame-Sánchez, C. (2014). Relationship marketing management: Its importance in private label extension. Journal of Business Research, 67(5), 667-672.

Mollen, A., and Wilson, H. (2010). Engagement, telepresence and interactivity in online consumer experience: Reconciling scholastic and managerial perspectives. Journal of Business Research, 63(9-10), 919-925.

Morgan, R. M., and Hunt, S. D. (1994). The Commitment-Trust Theory of Relationship Marketing. Journal of Marketing, 58(July), 20-38.

Napoli, J., Dickinson, S. J., Beverland, M. B., and Farrelly, F. (2014). Measuring consumer-based brand authenticity. Journal of Business Research, 67(6), 1090-1098.

Odin, Y., Odin, N., and Valette-Florence, P. (2001). Conceptual and operational aspects of brand loyalty An empirical investigation. Journal of Business Research, 53, 75-84.

Oliver, R. L. (1999). Whence Consumer Loyalty? Journal of Marketing, 63, 33-44.

Papista, E., and Dimitriadis, S. (2012). Exploring consumer-brand relationship quality and identification: Qualitative evidence from cosmetics brands. Qualitative Market Research: An International Journal, 15(1), 33-56.

Park, C. W., Eisingerich, A. B., Pol, G., and Park, J. W. (2013). The role of brand logos in firm performance. Journal of Business Research, 66(2), 180-187.

Phau, I., and Cheong, E. (2009). How Young Adult Consumers Evaluate Diffusion Brands: Effects of Brand Loyalty and Status Consumption. Journal of International Consumer Marketing, 21(2), 109-123.

Pillai, K. G., and Goldsmith, R. E. (2008). How brand attribute typicality and consumer commitment moderate the influence of comparative advertising. Journal of Business Research, 61(9), 933-941.

Prince, M., and Davies, M. (2002). Co-branding partners: What do they see in each other? Business Horizons, 45(5), 51-55.

Pritchard, M. P., Havitz, M. E., and Howard, D. R. (1999). Analyzing the CommitmentLoyalty Link in Service Contexts. Journal of the Academy of Marketing Science, 27(3), 333-348.

Rajagopal, P., and Votolato Montgomery, N. (2012). Remembering Better or Remembering Worse: Age Effects on False Memory. Advances in Consumer Research, 40, 928-929.

Raju, S., and Unnava, H. R. (2005). Brand Commitment and Size of the Consideration Set. Advances in Consumer Research, 32, 151-152.

Raju, S., Unnava, H. R., and Montgomery, N. V. (2009a). The Effect of Brand Commitment on the Evaluation of Nonpreferred Brands: A Disconfirmation Process. Journal of Consumer Research, 35(5), 851-863.

Raju, S., Unnava, H. R., and Montgomery, N. V. (2009b). The Moderating Effect of Brand Commitment on the Evaluation of Competitive Brands. Journal of 
Advertising, 38(2), 21-35.

Raju, S., and Unnava, R. H. (2006). The Mediating Role of Arousal in Brand Commitment. Advances in Consumer Research, 33, 517-519.

Robertson, T. S. (1976). Low-Commitment Consumer Behavior. Journal of Advertising Research, 16(2), 19-24.

Sahagun, M. A., and Vasquez-Parraga, A. Z. (2014). Can fast-food consumers be loyal customers, if so how? Theory, method and findings. Journal of Retailing and Consumer Services, 21(2), 168-174.

Shuv-Ami, A. (2012). Brand commitment: A new four-dimensional (4 Es) conceptualisation and scale. Journal of Customer Behaviour, 11(3), 281-305.

Smit, E., Bronner, F., and Tolboom, M. (2007). Brand relationship quality and its value for personal contact. Journal of Business Research, 60(6), 627-633.

Srivastava, P., and Owens, D. L. (2010). Personality traits and their effect on brand commitment: an empirical investigation. The Marketing Management Journal, 20(2), $15-27$.

Story, J., and Hess, J. (2010). Ethical brand management: customer relationships and ethical duties. Journal of Product \& Brand Management, 19(4), 240-249.

Sung, Y., and Campbell, W. K. (2009). Brand commitment in consumer-brand relationships: An investment model approach. Brand Management, 17(2), 97-113.

Sung, Y., and Choi, S. M. (2010). "I won't leave you although you disappoint me": The interplay between satisfaction, investment, and alternatives in determining consumerbrand relationship commitment. Psychology \& Marketing, 27(11), 1050-1074.

Sung, Y., Choi, S. M., and Tinkham, S. F. (2012). Brand-Situation Congruity: The Roles of Self-Construal and Brand Commitment. Psychology \& Marketing, 29(12), 941955.

Svendsen, M. F., Haugland, S. A., Gronhaug, K., and Hammervoll, T. (2011). Marketing strategy and customer involvement in product development. European Journal of Marketing, 45(4), 513-530.

Swaminathan, V., Reddy, S. K., and Dommer, S. L. (2012). Spillover effects of ingredient branded strategies on brand choice: A field study. Marketing Letters, 23(1), 237-251.

Sweeney, J., and Swait, J. (2008). The effects of brand credibility on customer loyalty. Journal of Retailing and Consumer Services, 15(3), 179-193.

Tanford, S. (2013). The impact of tier level on attitudinal and behavioral loyalty of hotel reward program members. International Journal of Hospitality Management, 34, 285-294.

Tanford, S., Raab, C., and Kim, Y. (2012). Determinants of customer loyalty and purchasing behavior for full-service and limited-service hotels. International Journal of Hospitality Management, 31(2), 319-328.

Tax, S. S., Brown, S. W., and Chandrashekaran, M. (1998). Customer evaluations of service complaint experiences: Implications for relationship marketing. Journal of Marketing, 62(2), 60-76.

Thomson, M., MacInnis, D. J., and Park, C. W. (2005). The Ties That Bind: Measuring the Strength of Consumers' Emotional Attachments to Brands. Journal of Consumer Psychology, 15(1), 77-91.

Tifferet, S., and Herstein, R. (2012). Gender differences in brand commitment, impulse buying, and hedonic consumption. Journal of Product \& Brand Management, 21(3), 176-182. 
Torres, A., and Tribó, J. A. (2011). Customer satisfaction and brand equity. Journal of Business Research, 64(10), 1089-1096.

Townsend, C., and Sood, S. (2012). Self-Affirmation through the Choice of Highly Aesthetic Products. Journal of Consumer Research, 39(2), 415-428.

Tranfield, D., Denyer, D., and Smart, P. (2003). Towards a methodology for developing evidence-informed management knowledge by means of systematic review. British Journal of Management, 14, 207-222.

Traylor, M. B. (1981). An exploratory study reveals the relationship between... Product Involvement and Brand Commitment. Journal of Advertising Research, 21(6), 51-56.

Tsai, S. (2011). Strategic relationship management and service brand marketing. European Journal of Marketing, 45(7/8), 1194-1213.

Tuškej, U., Golob, U., and Podnar, K. (2013). The role of consumer-brand identification in building brand relationships. Journal of Business Research, 66(1), 53-59.

Vivek, S. D., Beatty, S. E., and Morgan, R. M. (2012). Customer Engagement: Exploring Customer Relationships Beyond Purchase. Journal of Marketing Theory and Practice, 20(2), 127-145.

VonRiesen, R. D., Herndon, N. C., and VonRiesen, C. K. (2001). An Investigation of Attitude Toward the Brand, Commitment, and True Brand Loyalty in a CrossCultural Context. Journal of East-West Business, 7(1), 37-64.

Walker, K. (2010). A Systematic Review of the Corporate Reputation Literature: Definition, Measurement, and Theory. Corporate Reputation Review, 12(4), 357387.

Walsh, M. F., Winterich, K. P., and Mittal, V. (2010). Do logo redesigns help or hurt your brand? The role of brand commitment. Journal of Product \& Brand Management, 19(2), 76-84.

Wang, G. (2002). Attitudinal Correlates of Brand Commitment. Journal of Relationship Marketing, 1(2), 57-75.

Warrington, P., and Shim, S. (2000). An Empirical Investigation of the Relationship between Product Involvement and Brand Commitment. Psychology \& Marketing, 17(9), 761-782.

Wolny, J., and Mueller, C. (2013). Analysis of fashion consumers' motives to engage in electronic word-of-mouth communication through social media platforms. Journal of Marketing Management, 29(5-6), 562-583.

Zhang, J., and Bloemer, J. (2011). Impact of value congruence on affective commitment: examining the moderating effects. Journal of Service Management, 22(2), 160-182. 